\title{
HLA-linked C2 deficiency in a Dutch patient with systemic lupus erythematosus
}

\author{
L. BERRENS, H. BAART DE LA FAILLE, AND E. BORST-EILERS ${ }^{1}$ \\ From the Department of Dermatology, and ${ }^{1}$ Blood Bank, University Hospital, Utrecht, \\ The Netherlands
}

SUMMARY A patient with systemic lupus erythematosus was studied whose blood serum on repeated occasions showed undetectable levels of haemolytic complement (C). A detailed investigation of individual $\mathrm{C}$ components in the serum of the proposita and her family revealed the absence of functional $\mathrm{C} 2$ in the patient and half-normal values in the relatives. C4 levels in the family, but not in the patient, were above normal, whereas the levels of factor B were low in all cases. No abnormalities were noted in C3, C9, or C1̄INH. Tissue typing showed linkage of the C2-deficiency gene with the HLA-A10/B18 and A9/B18 haplotypes. No linkage with red cell antigens and no relationship with plasma kallikrein levels was found.

Many defects of complement components have been described in man $(\mathrm{C} 1 \mathrm{r}, \mathrm{C} 2, \mathrm{C} 3, \mathrm{C} 4, \mathrm{C} 5, \mathrm{C} 6, \mathrm{C} 7, \mathrm{C} 8$, CîINH, C3bINH). The clinical manifestations reported in association with these defects are strikingly diverse. The rare deficiency of $\mathrm{C} 2$ production appears to predispose to serious susceptibility to infection, vascular and mesenchymal disease, renal disease, and, particularly, lupus erythematosus (LE) (Day et al., 1973). Most patients with C2 deficiency studied so far had lupus erythematosus, systemic (SLE), discoid (DLE), or both (Agnello et al., 1972; Day et al., 1975; Fu et al., 1975; Wolski et al., 1976; Ochs et al., 1977), although cases with recurrent throat infections, urinary tract infections, anaphylactoid purpura, or rheumatic diseases have been described (Gelfand et al., 1975; Gibson et al., 1976). In addition to $\mathrm{C} 2$ deficiency, abnormal $\mathrm{C} 1$ has also been described in a patient with LE (Pondman et al., 1968). LE, of course, occurs most frequently in patients with no apparent abnormalities of the complement system.

Linkage of the $\mathrm{C} 2$ gene with the major histocompatibility complex (MHC) has been well documented. The gene coding for $\mathrm{C} 2$ has been located on chromosome 6, close to the HLA-D locus and at less than 5 centimorgans from the HLA-B locus (Ochs et al., 1977). The same chromosome carries the genes coding for the $\mathrm{C}$ components $\mathrm{C} 4, \mathrm{C} 6, \mathrm{C} 8$, and factor $\mathrm{B}$, the latter (Bf) being closely linked to the $\mathrm{C2}$ locus (Alper, 1976; Merrit et al., 1976; Teisberg et

Received for publication 14 December 1978 al., 1976). Analysis of HLA anjigens in families carrying the $\mathrm{C} 2$ deficiency gene has shown an association between $\mathrm{C} 2$ deficiency and HLA-A10 and B18, particularly the latter. We report the case of a Dutch homozygous C2-deficient patient carrying the A10/B18 and A9/B18 haplotypes.

\section{Material and methods}

\section{CASE REPORT}

The proposita, a Caucasian woman, born on 5 November 1950, had been known to our department since 1968 when she was referred because of a generalised, symmetrical, erythematopapulosquamous eruption with characteristic butterfly distribution on the face. She had livid, ulcerating lesions on the hands and feet together with distinct Raynaud's phenomenon. The eruption had developed after accidental burning of the face. On admission the patient was severely ill with fever up to $40^{\circ} \mathrm{C}$, and there were signs of polyarthritis. A diagnosis of SLE was made, which was confirmed by laboratory findings, notably characteristic immunofluorescence of a skin biopsy, positive ANA, positive LE cell test, leucopenia, and hypergammaglobulinaemia. Normal values were obtained for haemoglobin, platelets, serum urea, creatinine, electrolytes, bilirubin, alkaline phosphatase, transaminases, and lipids. The Coombs' test was negative with anti gammaglobulin and was positive with an anti complement (C3) serum (titre 1:16); there were no abnormalities of the clotting system. Haemolytic 
activity of the complement (C) system was not demonstrable.

Soon after admission a severe psychiatric syndrome developed, consisting of psychosis, bradyphrenia, depression, and amentia. The clinical picture was complicated by various infections, for example, of the respiratory and urinary tracts, and sepsis with Pseudomonas aeruginosa ensued. Up to now there have been exacerbations of the disease on numerous occasions; in fact, complete remission has not been observed so far. During exacerbations the skin condition often resembled the picture described above; in addition, a characteristic 'light-sensitive dermatitis' or discoid LE were also observed. Twice, a severe neuropsychiatric syndrome with psychosis and extrapyramidal symptoms dominated the picture. Other organ systems were not involved, and, especially, LE-nephritis, haemolysis, and bleeding tendency were never observed. Infections, for example, pyoderma, otitis media, sinusitis, bronchopneumonia, cystitis, pyelitis, and sepsis, often occurred. Despite repeated and urgent advice to practise contraception, the patient became pregnant in 1971. Remarkably, the course of the disease remained relatively benign, and she delivered a boy who was dysmature (birth weight $1890 \mathrm{~g}$ ) but who did not develop signs of LE. The further development of the child has been uneventful.

In 1973, the patient was given a contraceptive ( $500 \mathrm{mg}$ medroxyprogesterone acetate) intramuscularly. A flare-up of the disease resulted, again with involvement of the central nervous system. Therapy included the administration of prednisone, azathioprine, and chloroquine in varying doses and combinations. During the psychotic episodes, very high doses of prednisone were necessary to control the symptoms. Furthermore, antibiotic and antipsychotic treatment was given when indicated. Sterilisation was performed in 1974.

On various occasions during the last few years, laboratory evidence has been obtained of autoimmune activity, for example, false-positive treponemal serology, ANA, anti-double-stranded-DNA, positive LE cell tests, and cytotoxic anti-leucocyte antibodies. Immunofluorescence of the uninvolved skin revealed granular deposits at the dermoepidermal junction of $\mathrm{IgA}, \mathrm{IgG}, \mathrm{IgM}, \mathrm{Clq}, \mathrm{C} 4$, and $\mathrm{C} 3$ factors. $\mathrm{Clq}, \mathrm{C} 3$, and IgM were also present in the superficial capillary walls.

No member of the family had a medical history suggestive of LE (Table 3).

\section{HLA and blood group typing}

HLA typing was done by the NIH standard microlymphocytotoxicity technique, using 140 well-defined antisera to 35 specificities. Blood group typing was done by traditional agglutination techniques.

\section{Complement components}

Blood samples were collected by venepuncture. Citrated plasma and serum (after clotting in glass) were obtained from the samples and stored in small aliquots at $-70^{\circ} \mathrm{C}$ until used. Total haemolytic $\mathrm{C}$ was determined with serial serum dilutions, using $5 \times 10^{8}$ sheep erythrocytes (E) optimally sensitised with rabbit amboceptor (A); $\mathrm{CH}_{50}$ values were read from van Krogh plots. Functional C2 was determined by molecular titration using EA 1,4 cellular intermediates, as described by Borsos et al. (1961), with some slight modifications (Berrens et al., 1976). C components $\mathrm{C} 3, \mathrm{C} 5$, and $\mathrm{B}$ were determined immunochemically by single radial immunodiffusion using commercially available antibody-containing agarose plates (Behringwerke, Marburg/Lahn, Germany). Component $\mathrm{C} 9$ and the inhibitor CîINH were assayed by electroimmunodiffusion, according to Laurell (1966), using commercial rabbit antisera as described by Berrens et al. (1976).

Plasma (pre)kallikrein was evaluated according to Ratnoff and Saito (1976) with the synthetic amide $N$ - $\alpha$-benzoyl-L-proline-L-phenylalanine-L-arginine$\mathrm{HCl}$ (PPAN) (Pentapharm, Basel, Switzerland); $0.25 \mathrm{ml}$ of plasma was mixed with $0.25 \mathrm{ml}$ dextran sulphate (MW 500000 , Pharmacia, Sweden, 25 $\mu \mathrm{g} / \mathrm{ml}$ ) and kept at $0^{\circ} \mathrm{C}$ for 10 minutes. After another 10 minutes at room temperature, $0.25 \mathrm{ml}$ of the mixture and $0.25 \mathrm{ml}$ of substrate solution $(0.18 \mu \mathrm{M})$ were brought into a cuvette with $2 \mathrm{ml} 0.15 \mathrm{M}$ Trisimidazole buffer, $\mathrm{pH} 7 \cdot 9$, at $37^{\circ} \mathrm{C}$. The reaction was followed by observing the increment of extinction at $405 \mathrm{~nm}$ with the rate analyser of the Unicam SP1800 spectrophotometer. The results are expressed in $\mathrm{mU}$ kallikrein/ml, as described in the manufacturer's manual, taking the extinction change in the third minute as the basis for calculation.

\section{Results}

The patient's serum was examined several times over a number of years but was never found to contain detectable haemolytic C. Analysis of the individual C components showed an absence of functionally active $C 2$ in every sample (Table 1 ). The levels of the components $\mathrm{B}$ and $\mathrm{C} 4$ fluctuated between approximately half-normal and normal, possibly dependent on the activity of the disease. No striking abnormalities were observed in the serum levels of $\mathrm{C} 3$ or C1INH (Table 1), although the values in the proposita were higher than in other members of the family (Table 2 ). The C9 level, expressed in percent of a normal serum pool, was above the range of normal values observed in this laboratory, which 
might reflect its nature as an acute-phase protein (Kawachi-Takahashi et al., 1975).

Members of the patient's family available for study were investigated on two occasions, with an interval of about one year. As shown in Table 2, all subjects had half-normal values of functional $\mathbf{C 2}$ in the blood serum, causing low $\mathrm{CH}_{50}$ values in only one member (subject 8). The levels of factor B were depressed below the normal range in each member of the family, confirming earlier findings of linkage between the genes coding for $\mathrm{C} 2$ and factor $\mathrm{B}$ (Alper, 1976). C4 and CîINH levels were in the upper normal range; no apparent deviation was noted in the serum levels of the protease inhibitors $\alpha_{1}$-antitrypsin $\left(\alpha_{1} \mathrm{AT}\right)$ and $\alpha_{2}$-macroglobulin $\left(\alpha_{2} \mathrm{M}\right)$.

Similar results were observed during the second investigation of the relatives. This time, low levels of total haemolytic $\mathrm{C}$ were found in subject 1 but not in subject 8. As shown in Table 3, C2 and B levels were again depressed to approximately half-normal values, while C4 was in the upper range or slightly above normal. The plasma prekallikrein levels in all subjects, including the proposita, were not signi- ficantly different from those observed in normal volunteers (Table 3).

The results shown in Tables 1,2 , and 3 are suggestive of hereditary transmission of $\mathrm{C} 2$ deficiency and indicate that the proposita is homozygous for the trait and the (clinically unaffected) members of the family are all heterozygous for this defect. As shown by the results of HLA-typing (Figure), all members of the family are also heterozygous for the antigen B18, while the proposita is homozygous. These results are in full accord with an association between C2 deficiency and B18 phenotype, as described in the literature (Fu et al., 1975; Gibson et al., 1976; Opelz and Glovsky, 1976).

As expected, no genetic linkage was found between $\mathbf{C} 2$ deficiency and the red cell blood group antigens (Table 4).

\section{Discussion}

The results of this study are suggestive of the hereditary transmission of $\mathbf{C} 2$ deficiency as an autosomal recessive trait, the proposita being

Table 1 Longitudinal analysis of serum samples in the proposita

\begin{tabular}{|c|c|c|c|c|c|c|c|c|}
\hline Date & $\begin{array}{l}\mathrm{CH}_{\mathrm{so}} / \mathrm{ml} \\
(\% \text { of } \\
\text { normal })\end{array}$ & $\mathrm{C} 2 \mathrm{H}_{50} / \mathrm{ml}$ & $\begin{array}{l}\text { Factor B } \\
(\mathrm{mg} / 100 \mathrm{ml})\end{array}$ & $\begin{array}{l}C 4 \\
(\mathrm{mg} / 100 \mathrm{ml})\end{array}$ & $\begin{array}{l}C 3(\beta 1 A / C) \\
(m g / 100 \mathrm{ml})\end{array}$ & $\begin{array}{l}C 9 \\
(\% \text { of } \\
\text { normal })\end{array}$ & $\begin{array}{l}\text { CiINH } \\
(\mathrm{mg} / 100 \mathrm{ml})\end{array}$ & Clinical picture \\
\hline $\begin{array}{l}3 \text { Oct'74 } \\
15 \text { Sept '75 } \\
13 \text { Feb'76 } \\
20 \text { Apr'77 } \\
23 \text { Jun'77 } \\
14 \text { Jul'77 }\end{array}$ & $\begin{array}{l}\mathbf{0} \\
\mathbf{0} \\
\mathbf{0} \\
\mathbf{0} \\
\mathbf{0} \\
\mathbf{0}\end{array}$ & $\begin{array}{l}0 \\
0 \\
0 \\
0 \\
0 \\
0\end{array}$ & $\begin{array}{l}\text { ND } \\
11 \cdot 2 \\
19 \cdot 2 \\
20 \cdot 8 \\
18 \cdot 8 \\
20 \cdot 2\end{array}$ & $\begin{array}{r}9 \cdot 8 \\
6 \cdot 4 \\
9 \cdot 2 \\
20 \cdot 4 \\
15 \cdot 0 \\
15 \cdot 6\end{array}$ & $\begin{array}{r}98 \\
134 \\
114 \\
146 \\
130 \\
127\end{array}$ & $\begin{array}{l}\text { ND } \\
148 \\
165 \\
\text { ND } \\
161 \\
177\end{array}$ & $\begin{array}{l}25 \cdot 0 \\
40 \cdot 8 \\
43 \cdot 9 \\
\text { ND } \\
\text { ND } \\
\text { ND }\end{array}$ & $\begin{array}{l}\text { Remission } \\
\text { Flare-up due to sunlight } \\
\text { Skin active; arthritis } \\
\text { Mild activity; arthralgia } \\
\text { Mild activity; arthralgia } \\
\text { Remission }\end{array}$ \\
\hline Normal range & $75-125$ & $1200-2000$ & $20-30$ & $20-45$ & $60-120$ & $75-125$ & $20-35$ & \\
\hline
\end{tabular}

ND $=$ not detected

Table 2 Complement components and enzyme inhibitors in the family, 1st series (1975)

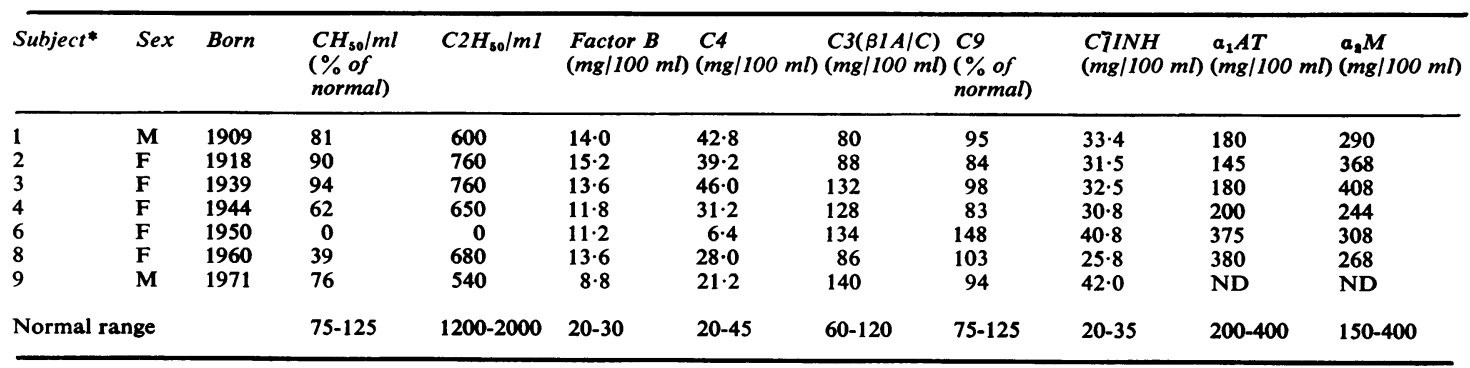

*Subjects numbered as indicated in the Figure. Subject 6 is the proposita. 
Table 3 Complement components and prekallikrein levels (in plasma) in the family, 2nd series (1976)

\begin{tabular}{|c|c|c|c|c|c|c|c|c|c|c|}
\hline Subject* & Sex & Born & $\begin{array}{l}\mathrm{CH}_{\mathrm{so}} / \mathrm{ml} \\
(\% \text { of } \\
\text { normal })\end{array}$ & $C 2 H_{50} / m l$ & $\begin{array}{l}\text { Factor B } \\
(\mathrm{mg} / 100 \mathrm{ml})\end{array}$ & $\begin{array}{l}C 4 \\
(\mathrm{mg} / 100 \mathrm{ml})\end{array}$ & $\begin{array}{l}C 3(\beta 1 A / C) \\
(\mathrm{mg} / 100 \mathrm{ml})\end{array}$ & $\begin{array}{l}C 9 \\
(\% \text { of } \\
\text { normal })\end{array}$ & $\begin{array}{l}\text { CĭINH } \\
(\mathrm{mg} / 100 \mathrm{ml})\end{array}$ & $\begin{array}{l}\text { Prekallikrein } \\
(m U / m l)\end{array}$ \\
\hline 1 & $\mathbf{M}$ & 1909 & 23 & 800 & $17 \cdot 0$ & $50 \cdot 8$ & 110 & 119 & $35 \cdot 2$ & 60 \\
\hline 2 & F & 1918 & 80 & 600 & 15.0 & 41.4 & 118 & 87 & $31 \cdot 7$ & 80 \\
\hline 3 & $\mathbf{F}$ & 1939 & 70 & 820 & $15 \cdot 8$ & 52.8 & 110 & 117 & $29 \cdot 0$ & 76 \\
\hline 4 & F & 1944 & 68 & 840 & $13 \cdot 8$ & $41 \cdot 4$ & 104 & 101 & $31 \cdot 3$ & 52 \\
\hline 5 & $\mathbf{M}$ & 1949 & 58 & 620 & $12 \cdot 4$ & $34 \cdot 0$ & 90 & 83 & $32 \cdot 3$ & 44 \\
\hline 6 & $\mathbf{F}$ & 1950 & 0 & 0 & $19 \cdot 2$ & $9 \cdot 2$ & 114 & 165 & 43.9 & 68 \\
\hline 7 & $\mathbf{M}$ & 1952 & 78 & 580 & $16 \cdot 8$ & 51.6 & 110 & 86 & $34 \cdot 9$ & 56 \\
\hline 8 & F & 1960 & 60 & 540 & 10.4 & $31 \cdot 2$ & 104 & 90 & $27 \cdot 9$ & 68 \\
\hline 9 & $\mathbf{M}$ & 1971 & 76 & 540 & $8 \cdot 8$ & $21 \cdot 2$ & 140 & 94 & $42 \cdot 0$ & ND \\
\hline \multicolumn{3}{|c|}{ Normal range } & $75-125$ & $1200-2000$ & $20-30$ & $20-45$ & $60-120$ & $(100)$ & $20-35$ & $60-100$ \\
\hline
\end{tabular}

*Subjects numbered as shown in the Figure. Subject 6 is the proposita.

Table 4 Red cell typing of the family

\begin{tabular}{|c|c|c|c|c|c|c|c|c|}
\hline Subject & $A B O$ & Rhesus & $M N S$ & $P_{1}$ & Kell & $F y^{a}$ & $L u^{\mathrm{a}}$ & $C^{w}$ \\
\hline $\begin{array}{l}1 \\
2 \\
3 \\
4 \\
5 \\
6 \\
7 \\
8\end{array}$ & $\begin{array}{l}\mathbf{O} \\
\mathbf{A}_{2} \\
\mathbf{O} \\
\mathbf{A}_{2} \\
\mathbf{A}_{2} \\
\mathbf{O} \\
\mathbf{A}_{2} \\
\mathbf{O}\end{array}$ & $\begin{array}{l}\text { CcDEe } \\
\text { CcDee } \\
\text { CcDee } \\
\text { ccDEe } \\
\text { CCDee } \\
\text { CcDEe } \\
\text { CCDee } \\
\text { CCDee }\end{array}$ & $\begin{array}{l}\text { MNS - } \\
\text { MNS - } \\
\text { MNS - } \\
\text { MNS - } \\
\text { MNS - } \\
\text { MNS - } \\
\text { MNS - } \\
\text { MNS - }\end{array}$ & $\begin{array}{l}\mathbf{P}_{1}- \\
\mathbf{P}_{1}+ \\
\mathbf{P}^{-} \\
\mathbf{P}_{1}+ \\
\mathbf{P}_{1}+ \\
\mathbf{P}_{1}- \\
\mathbf{P}_{1}- \\
\mathbf{P}_{1}+\end{array}$ & $\begin{array}{l}\text { Kell- } \\
\text { Kell- } \\
\text { Kell- } \\
\text { Kell- } \\
\text { Kell- } \\
\text { Kell- }^{-} \\
\text {Kell- } \\
\text { Kell- }\end{array}$ & 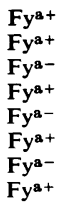 & $\begin{array}{l}\mathbf{L u}^{\mathbf{a}-} \\
\mathbf{L} \mathbf{u}^{\mathbf{a}-} \\
\mathbf{L} \mathbf{u}^{\mathbf{a}-} \\
\mathbf{L} \mathbf{u}^{\mathbf{a}-} \\
\mathbf{L} \mathbf{u}^{\mathbf{a}-} \\
\mathbf{L} \mathbf{u}^{\mathbf{a}-} \\
\mathbf{L} \mathbf{u}^{\mathbf{a}-} \\
\mathbf{L} \mathbf{u}^{\mathbf{a}-}\end{array}$ & $\begin{array}{l}C^{w-} \\
C^{w-} \\
C^{w-} \\
C^{w-} \\
C^{w-} \\
C^{w-} \\
C^{w-} \\
C^{w-}\end{array}$ \\
\hline
\end{tabular}

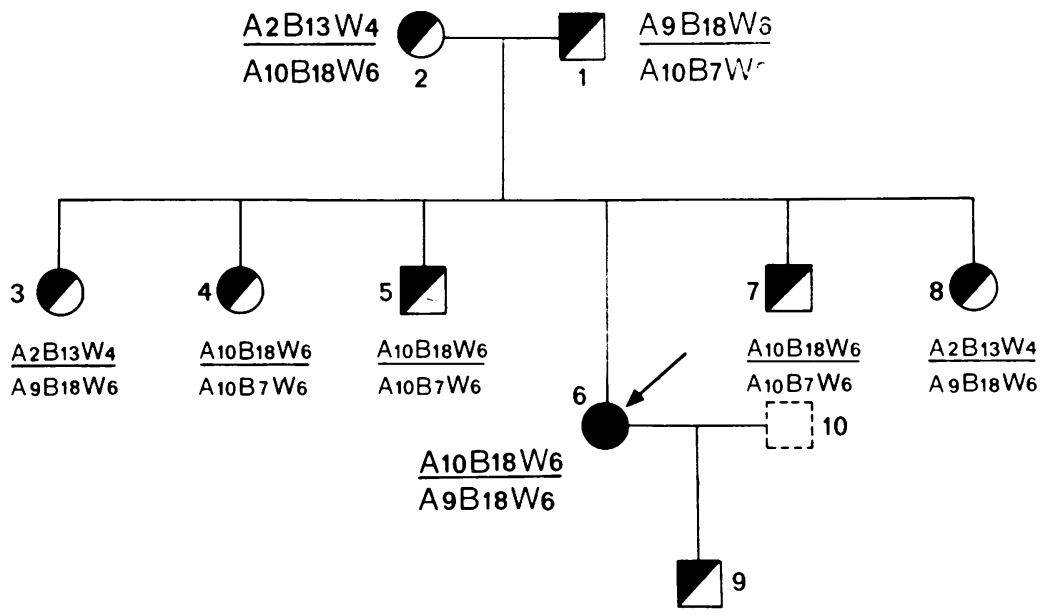

Figure Pedigree of the family of a patient with systemic lupus erythematosus (proposita, arrow). HLA-haplotypes indicated. Subject 10 was not available for investigation and subject 9 was not typed.

homozygous and all members of the family heterozygous. This investigation further confirms the close linkage between the $\mathrm{C} 2$ gene and the HLA genes, because the $\mathrm{C} 2$ deficiency traits in the family segregate with the HLA haplotypes. The HLAassociation would have been even more firmly established had one of the siblings carried the haplotypes A10/B7 and A2/B13 and shown a normal level of C2.
The depressed levels of factor $\mathrm{B}$ in the relatives also confirm the close linkage between the $\mathrm{Bf}$ and $\mathrm{C} 2$ loci, as has been reported before (Alper, 1976). The fact that factor $B$ in the proposita on occasions reached normal levels may be due to its reported behaviour as an acute-phase protein (Schutte et al., 1974), as has also been described for C9 (KawachiTakahashi et al., 1975).

The association between $\mathrm{C} 2$ deficiency and the 
HLA-B18 antigen is also confirmed in our study. In most families described in the literature, $\mathrm{C} 2$ deficiency was associated with the haplotypes $\mathrm{A} 10 / \mathrm{B} 18$, for example, in 8 out of 10 families described by Gibson et al. (1976). In our patient, this haplotype is present on the maternal chromosome. The paternal chromosome also carries the $\mathrm{B} 18$, but in this case it is part of the A9/B18 haplotype. Opelz and Glovsky (1976) have suggested that $\mathrm{C} 2$ deficiency may have originated in an individual with the A10/B18 haplotype, but that the association with A10 may subsequently have become lost due to crossing over.

Although C2 deficiency is rare in groups of LE patients, it is nevertheless evident that individuals homozygous for the abnormality have a striking predisposition to LE. In a series of 38 homozygous, C2-deficient subjects described by Agnello (1976), 14 had LE (6 SLE, 5 DLE, 3 both). Nine patients had other diseases, and 15 were apparently healthy. The clinical characteristics of the C2-deficient LE patients appear to consist of a preponderance of discoid lesions, a low incidence of renal disease, a low incidence and titres of anti DNA antibodies, and a low frequency of immunoglobulin and $\mathrm{C}$ deposits in the skin.

The clinical picture of our proposita consisted of skin lesions much more extensive than discoid LE, together with arthritis and recurrent involvement of the central nervous system. LE nephritis did not occur in our patient during the period of observation. Deposits of immunoglobulin and $\mathrm{C}$ factors were observed in the skin, low titres of anti-doublestranded-DNA were occasionally demonstrable, there were circulating immune complexes, and cytotoxic antibodies against leucocytes were detectable. It seems remarkable that, despite these autoallergic phenomena, LE nephritis has not developed. It is tempting to speculate that $\mathrm{C} 2$ deficiency in this respect may offer some protection, because immune complexes in such patients might fail to generate the C3 and C5 fragments essential for the recruitment of cellular and humoral mediators of inflammation.

\section{References}

Agnello, V. (1976). Poster presentation. Proceedings of the International Symposium on HLA and Disease, p. 296. Inserm, Paris.

Agnello, V., De Bracco, M. M. E., and Kunkel, H. G. (1972). Hereditary C2-deficiency with some manifestations of systemic lupus erythematosus. Journal of Immunology, 108, 837-840.

Alper, C. A. (1976). Inherited structural polymorphism in human $\mathrm{C} 2$ : evidence for genetic linkage between $\mathrm{C2}$ and bf. Journal of Experimental Medicine, 144, 1111-1115.
Berrens, L., Jankowski, E., and Jankowski-Berntsen, I. (1976). Complement component profiles in urticaria, dermatitis herpetiformis, and alopecia areata. British Journal of Dermatology, 95, 145-152.

Borsos, T., Rapp, H. J., and Mayer, M. M. (1961). Studies on the second component of complement. I. The reaction between $E^{\prime} C^{\prime} 1,4$ and $C^{\prime} 2$ : evidence on the single site mechanism of immune hemolysis and determination of C'2 on a molecular basis. Journal of Immunology, 87, 310-325.

Day, N. K., Geiger, H., McLean, R., Michael, A., and Good, R. A. (1973). C2-deficiency: development of lupus erythematosus. Journal of Clinical Investigation, 52, 1601-1607.

Day, N. K., l'Espérance, P., Good, R. A., Michael, A. F., Hansen, J. A., Dupont, B., and Jersild, C. (1975). Hereditary C2-deficiency: genetic studies and association with the HL-A system. Journal of Experimental Medicine, 141, 1464-1469.

Fu, S. M., Stern, R., Kunkel, H. G., Dupont, B., Hansen, J. A., Day, N. K., Good, R. A., Jersild, C., and Fotino, M. (1975). Mixed lymphocyte culture determinants and C2-deficiency: LD-7A associated with C2-deficiency in four families. Journal of Experimental Medicine, 142, 495-506.

Gelfand, E. W., Clarkson, J. E., and Minta, J. O. (1975). Selective deficiency of the second component of complement in a patient with anaphylactoid purpura. Clinical Immunology and Immunopathology, 4, 269-276.

Gibson, D. J., Glass, D., Carpenter, C. B., and Schur, P. H. (1976). Hereditary C2-deficiency: diagnosis and HLA gene complex associations. Journal of Immunology, 116, 1065-1070.

Kawachi-Takahashi, S., Tanaka, K., Takahashi, M., Kawashima, T., and Shimada, K. (1975). Determination of serum $\mathrm{C} 9$ level by immunodiffusion. Elevation in patients with infections or allergic skin diseases. International Archives of Allergy, 48, 161-170.

Laurell, C. B. (1966). Quantitative estimation of proteins by electrophoresis in agarose gel containing antibodies. Analytical Biochemistry, 15, 45-52.

Merrit, A. D., Petersen, B. H., Biegel, A. A., Meyers, D. A., Brooks, S. F., and Hodes, M. E. (1976). Chromosome 6: linkage of the eighth component of complement (C8) to the histocompatibility region (HLA). Cytogenetics and Cell Genetics, 16, 331-334.

Ochs, H. D., Rosenfeld, S. I., Thomas, E. D., Giblett, E. R., Alper, C. A., Dupont, B., Schaller, J. G., Gilliland, B. C., Hansen, J. A., and Wedgwood, R. J. (1977). Linkage between the gene (or genes) controlling synthesis of the fourth component of complement and the major histocompatibility complex. New England Journal of Medicine, 296, 470-475.

Opelz, G., and Glovsky, M. M. (1976). HLA antigen studies in a family with C2 deficiency. Journal of Immunogenetics, 3, 303-306.

Pondman, K. W., Stoop, J. W., Cormane, R. H., and Hannema, A. J. (1968). Abnormal $\mathrm{Cl}$ in a patient with systemic lupus erythematosus (Abstract). Journal of Immunology, 101, 811.

Ratnoff, O. D., and Saito, H. (1976). Evidence that Fitzgerald Factor counteracts inhibition by kaolin or 
ellagic acid of the amidolytic properties of a plasma kallikrein. Blood, 47, 243-251.

Schutte, M., DiCamelli, R., Murphy, P., Sadove, M.,and Gewurz, H. (1974). C3 Proactivator (C3PA) as an acute phase reactant. Clinical and Experimental Immunology, 18, 251-256.

Teisberg, P., Akesson, I., Olaisen, B., Gedde-Dahl, T., Jr., and Thorsby, R. (1976). Genetic polymorphism of C4 in man and localisation of a structural $\mathrm{C} 4$ locus to the HLA gene complex of chromosome 6. Nature, 264,
253-254.

Wolski, K. P., Schmid, F. R., and Mittal, K. K. (1976). Genetic linkage between the HL-A system and a deficit of the second component (C2) of complement in four generations of a family. Tissue Antigens, 7, 35-38.

Requests for reprints to: Dr L. Berrens, Department of Dermatology, University Hospital, Catharijnesingel 101, 3500 CG Utrecht, The Netherlands. 